\title{
STWORZENIE I EWOLUCJA - DWA „PUZZLE” CHRZEŚCIJAŃSKIEGO ŚWIATOPOGLĄDU
}

\begin{abstract}
Streszczenie. Problem relacji między religią i nauką, rozumiany jako relacja między doktryną chrześcijańską i naukami przyrodniczymi, jest dzisiaj powszechnie znany i dyskutowany. Artykuł podejmuje bardzo praktyczne zagadnienie, jakim jest formowanie oraz rewidowanie światopoglądu chrześcijańskiego w kontekście spotkania się w człowieku religijnym dwóch wielkich idei: stworzenia i ewolucji. Wychodząc od zaproponowanej definicji światopoglądu, w artykule zostanie ukazany fundamentalny rys światopoglądu chrześcijańskiego oraz jego istotne cechy. Dopiero w takim świetle próbuje się przedstawić propozycję interpretacji spotkania i wzajemnego oddziaływania idei stworzenia i ewolucji. Zaproponowana relacja dialogu jest drogą do zdobywania dojrzałej postawy względem rzeczywistości zarówno dla człowieka religijnego, jak i dla ludzi uprawiających nauki przyrodnicze. Jednocześnie jest to propozycja, która, prowadząc do wewnętrznej integracji człowieka, może stać się odpowiedzią na niektóre współczesne kryzysy kultury.
\end{abstract}

Słowa kluczowe: stworzenie, ewolucja, kreacjonizm, ewolucjonizm, kosmologia, światopogląd chrześcijański, dialog nauka - religia, pytania metafizyczne, Michał Heller

1. Światopogląd - definicja, rodzaje i uwagi. 2. Teoria ewolucji oraz standardowy model kosmologiczny w ogólnym zarysie. 3. Kreacjonizm a ewolucja - niektóre pytania i problemy światopoglądu chrześcijańskiego. 3.1. Zarys historyczno-teologicznego komentarza do biblijnego opisu stworzenia. 3.2. Kosmologiczne tło obrazu świata. 3.3. Kłopoty wokół Wielkiego Wybuchu. 4. Pytania metafizyczne... zamiast zakończenia.

Każdego dnia człowiek podejmuje rozmaite praktyczne działania, starając się osiągać określone cele. Jednocześnie nie tylko chce sprawnie działać, ale także wiedzieć: co, jak i dlaczego istnieje. Teoria i praktyka pozostają ze sobą w ścisłym związku, chociaż bardzo często zdarza się i tak, że między jedną a drugą perspektywą życia ludzkiego występuje konflikt albo, łagodniej mówiąc, brak spójności. Przyczynami takiego stanu rzeczy mogą być ogólnie mówiąc błędy poznawcze. Oczywiste jest, że taka sytuacja nie należy do rzadkości 
w przypadku ludzi religijnych (akcent zostanie położony na religię chrześcijańską). Natomiast szczególnym przypadkiem w tym temacie jest kwestia spotkania się poglądów religijnych (źródłem jest Objawienie, wiara chrześcijańska) i naukowych. „Nowożytne nauki przyrodnicze posiadają kilka organizujących je, prostych idei; jedną $z$ nich jest idea ewolucji, zgodnie $z$ nią każdy naturalny rodzaj rzeczy stał się tym, czym jest, przebywając długą drogę stopniowego rozwoju, którą można śledzić, cofając się w czasie. W chrześcijańskiej tradycji teologia również pracuje w oparciu o kilka podstawowych idei; jedną z nich jest idea stworzenia, zgodnie z którą wszechświat w swoim istnieniu zależy od transcendentnego Boga. Te dwie idee oddziaływały na siebie w bardzo złożony sposób w ciągu stuleci i nadal na siebie oddziaływują"1.

Niestety dla wielu chrześcijan owo „oddziaływanie” przybiera charakter konfliktu prowadzącego do konieczności decyzji: „albo - albo” lub - być może częściej - do uproszczonych eklektycznych syntez bądź sceptycznego zawieszenia sądu. Ujawniają się w ten sposób rozmaite problemy ignorancji religijnej czy naukowej. Sprawę braków dostatecznej wiedzy w różnych dziedzinach można do pewnego stopnia tłumaczyć tym, że bardzo szybki rozwój nauk szczegółowych i postępująca wciąż specjalizacja zawodowa nie ułatwiają pojedynczej osobie opanowania choćby jednego działu wiedzy. Natomiast osobnym problemem wydaje się być potwierdzanie albo rewidowanie czy po prostu rozumienie chrześcijańskiego światopoglądu. Jak w sposób racjonalny i krytyczny osoba religijna może dokonywać formowania i wyboru światopoglądu? Poszukiwanie i budowanie syntetycznego spojrzenia na całość spraw człowieka to nierzadko zadanie na całe życie. Może przypominać wieloelementową układankę (puzzle), z której na końcu wyłania się różnobarwny obraz.

1 Z Przedmowy do: Evolution and Creation, red. E. McMullin, Notre Dame 1985, cyt. za: M. Heller, Przedmowa do pierwszego i drugiego wydania polskiego, w: E. McMullin, Ewolucja i stworzenie, tłum. z ang. J. Rodzeń, Kraków 2014, 14. 
Wymaga to czasu, cierpliwości oraz - ogólnie to ujmując - poznania i rozumienia pewnych zasad związanych $z$ takim przedsięwzięciem ${ }^{2}$. $Z$ pewnością należy do tego zaliczyć określenie sobie: co to jest światopogląd; jakie są jego cechy; co stanowi szczególny rys światopoglądu chrześcijańskiego? Te zagadnienia stanowić będą pierwszą część niniejszego artykułu. W części drugiej przedstawione zostaną tylko dwa elementy tej złożonej „układanki”. Przede wszystkim chodzić będzie o uwyraźnienie istotnych pytań i problemów, które ukazują się przy spotkaniu tych dwóch wielkich idei: stworzenia i ewolucji. W świetle zaproponowanej definicji światopoglądu chrześcijańskiego, zostanie przedstawiona propozycja interpretacji łączenia tych idei w całościowym wyjaśnianiu świata. Jednocześnie będzie to próba wskazywania, jak owa interpretacja koreluje $\mathrm{z}$ istotnymi cechami chrześcijańskiego rozumienia rzeczywistości.

\section{1. ŚWIATOPOGLĄD - DEFINICJA, RODZAJE I UWAGI}

„Wszyscy ludzie z natury dążą do poznania” - przekonywał Arystoteles. Dowodem na to jest wartość jaką nadajemy naszym zmysłom, a wśród nich w sposób szczególny: zmysłowi wzroku. On bowiem „W najwyższym stopniu umożliwia nam poznanie i ujawnia wiele różnic”3. Chcemy widzieć (wiedzieć) z różnych względów (teoretycznych bądź praktycznych), jak „coś wygląda”, tzn. chcemy to zrozumieć. Zatem w naturze człowieka leży również pragnienie „zobaczenia” sensu w życiu rozumianym jako całość. Taką tendencję do całościowego układania wszystkich spraw i ustalania sensu życia można nazwać poszukiwaniem światopoglądu. Czym więc ostatecznie jest światopogląd?

2 Zob. S. Kamiński, Od spostrzeżeń do poglądu na świat, w: tenże, Światopogląd - Religia Teologia. Zagadnienia filozoficzne i metodologiczne, Lublin 1998, 13-31.

3 Arystoteles, Metafizyka, tłum. z gr. K. Leśniak, Warszawa 1983, księga I, 3. 
Polski termin, powszechnie przyjęty i stosowany, jest tłumaczeniem niemieckiego rzeczownika Weltanschauung, który w XVIII w. wprowadził F.E.D. Schleiermacher, a w drugiej połowie XIX w. rozpowszechnił W. Dilthey. Dosłownie oznacza więc: pogląd na świat konkretnej osoby ${ }^{4}$. A.B. Stępień definiuje go w następujący sposób: „(...) jest to zespół przekonań i postaw, twierdzeń, ocen i norm, który - przynajmniej w oczach zwolenników czy wyznawców - stanowi spójny, całościowy obraz rzeczywistości (tego, co istnieje), porządkujący (wartościujący i normujący) postępowanie względem siebie i otoczenia" 5 .

Krótko mówiąc, światopogląd to myślowa (duchowa) postawa człowieka wobec całej rzeczywistości dająca jej syntetyczny obraz, to pewien rodzaj ogólnej wiedzy, która pozwala na orientację i działanie w otaczającym świecie. W świetle powyższej definicji widać, z jak wielu rozmaitych elementów i czynników budowana jest taka duchowa postawa. Ukazuje się ona w zespole istotnych sądów dotyczących człowieka (kim jest, skąd się wziął, jaki jest cel i sens jego istnienia itd.), ludzkości (dokąd zmierza cała ludzkość), świata (skąd się wziął i dlaczego, jaki jest jego początek, dokąd zmierza itd.), wartości (pytania o dobro i zło itp.), Absolutu (czy istnieje, a jeżeli tak, to jaki jest Jego stosunek do człowieka i świata) oraz we wzajemnych relacjach człowieka do otoczenia ${ }^{6}$. M. Lubański zauważa, że im bardziej ów system sądów i przekonań ,jest logicznie spójny, uzasadniony i całościowy, tzn. nie pomija żadnej dziedziny i żadnego zagadnienia w niej występującego, tym bardziej wartościowy jest cały światopogląd"”.

Jednakże światopogląd człowieka nie jest czymś jednoznacznie uformowanym tylko na podstawie wyników czy twierdzeń

4 Por. W. Dłubacz, Światopogląd, w: Powszechna Encyklopedia Filozofii, t. 9, red. A. Maryniarczyk, Lublin 2008, 346.

5 A.B. Stępień, Wstęp do filozofii, Lublin 2001, 40.

6 Por. M. Lubański, Światopogląd, w: Katolicyzm A-Z, red. Z. Pawlak, Poznań 1997, 362-363.

7 Tamże. 
czerpanych z wiedzy naukowej, zarówno przyrodniczej, jak i humanistycznej. Istotną rolę odgrywa tutaj jeszcze tzw. element wolitywny i emocjonalny. Zasadniczym źródłem światopoglądu jest bowiem doświadczenie życiowe danego człowieka. W takim znaczeniu nie można mówić o światopoglądzie naukowo, racjonalnie uzasadnionym. I.M. Bocheński nawet dowodził, że „akt przyjęcia światopoglądu poprzedza rodzaj hipotezy wyjaśniającej, porządkującej całość doświadczenia danego człowieka, i to nie tylko doświadczenia faktów, ale także wartości moralnych, estetycznych itp. Taka hipoteza nie jest intersubiektywnie sprawdzalna, między innymi dlatego, że pole doświadczenia każdego $\mathrm{z}$ nas jest inne"8.

Jakkolwiek nie można mówić o dowodzeniu (w naukowym tego słowa znaczeniu) konieczności przyjęcia danej postawy myślowej, to można i należy wskazywać na pewne racje, na których dany światopogląd jest oparty. Mając to na uwadze, można wyróżnić trzy główne jego rodzaje: racjonalny (krytyczny), scjentystyczny oraz religijny. Zasadniczym rysem światopoglądu racjonalnego jest odwoływanie się do rozumu jako źródła poznania, a więc podejście krytyczne, eliminujące bądź ograniczające wpływ takich czynników, jak: emocje, popędy, nawyki itp. Odwołuje się on do nauk szczegółowych i filozoficznych zgodnie z zakresem ich kompetencji. Światopogląd scjentystyczny buduje obraz rzeczywistości, ufając wynikom czy twierdzeniom nauk szczegółowych. Natomiast o charakterze światopoglądu religijnego decyduje oparcie się na fundamencie jakiejś religii, z której czerpie się wszystkie podstawowe idee rozumienia świata. $\mathrm{W}$ centrum więc będzie zaufanie Bogu i Jego objawieniu?.

Należy teraz podkreślić fakt występowania szczególnego rodzaju światopoglądu religijnego, mianowicie chrześcijańskiego. Krótko mówiąc, u jego podstaw leży nauka Jezusa Chrystusa zawarta

8 I.M. Bocheński, Filozofia a światopogląd, Znak 37(1985)5, 6.

9 Por. A.B. Stępień, dz. cyt., 41 oraz W. Dłubacz, art. cyt., 346. 
w Ewangelii, a której przekazicielem jest Kościół Powszechny ${ }^{10}$. Wydaje się jednak, że o jego specyfice świadczy nie tyle odwoływanie się do objawienia judeo-chrześcijańskiego i przyjęcie konkretnych norm postępowania moralnego człowieka (to jest oczywiste!), ile przekonanie, że w jego budowaniu ogromną rolę odgrywa rozum. „Głosi się, że chrześcijanin ma obowiązek wiedzieć (nie tylko wierzyć), w co i dlaczego wierzy, że jego wiara ma być rozumna"11. Oznacza to m.in., że wiara nie powinna być sprzeczna $z$ trwałymi osiągnięciami nauki. Przyjmując Objawienie Boże, chrześcijanin nie tylko nie powinien negować trwałych osiągnięć naukowych, ale według M. Lubańskiego - „ma obowiązek przyjąć je bez wahania” ${ }^{2}$. Zatem jest to światopogląd nie tylko religijny, na który składa się wiara religijna i związany z tym stosunek do osoby Jezusa Chrystusa, ale także racjonalny i czerpiący $z$ wiedzy naukowej.

Za M. Lubańskim można wskazać kilka ważniejszych cech światopoglądu chrześcijańskiego. Są to: 1) uniwersalizm; 2) humanizm (istotowa równość między ludźmi); 3) personalizm (godność i wolność każdej osoby ludzkiej); 4) pluralizm (w różnym ujęciu i rozumieniu: przekonanie o wielości bytów, osób, wartości itp.); 5) antyfideizm; 6) spirytualizm (nieograniczanie rzeczywistości tylko do bytów czysto materialnych); 7) realizm (przekonanie o istnieniu i poznawalności obiektywnej rzeczywistości); 8) integralizm ${ }^{13}$.

10 Por. M. Lubański, art. cyt., 363.

11 W. Dłubacz, art. cyt., 346.

12 M. Lubański, art. cyt., 363. Kategoryczność takiego stwierdzenia może budzić czyjś niepokój o nadmierne przeakcentowanie czy nawet „dominację” wiedzy naukowej w kształtowaniu światopoglądu chrześcijańskiego. Nie sądzę, aby taka była intencja autora. „Przyjąć coś bez wahania" nie oznacza braku krytycyzmu czy namysłu nad danym problemem. Nie oznacza również specjalnych priorytetów dla twierdzeń naukowych. Czy chrześcijanin może w sposób krytyczny i odpowiedzialny nie przyjąć np. heliocentrycznego modelu układu słonecznego jako trwałego osiągnięcia nauki? Wypowiedź M. Lubańskiego wydaje się raczej sprzeciwem wobec światopoglądów opartych na koncepcjach religii uznających niemożliwość pogodzenia prawd rozumu (nauki) i wiary.

13 Por. tamże. 
W kontekście podejmowanego tutaj problemu „oddziaływania” na siebie idei stworzenia i ewolucji szczególnie należy podkreślić: uniwersalizm, antyfideizm ${ }^{14}$ oraz integralizm chrześcijańskiej postawy wobec świata.

\section{TEORIA EWOLUCJI ORAZ STANDARDOWY MODEL KOSMOLOGICZNY W OGÓLNYM ZARYSIE}

Praktycznie aż do połowy XIX w. człowiek był przekonany o niezmienności gatunków. Oznaczało to, że rośliny i zwierzęta nie podlegają ewolucji, więc dla światopoglądu przeciętnego człowieka świat przyrody pozostawał stały i niezmienny. Współczesna nauka pokazuje nam jednak, w sposób już dzisiaj niekwestionowany, że trzy miliardy lat temu życie na Ziemi miało bardzo prymitywną postać i w ciągu milionów lat zmieniało swoją formę, zwiększając stopień zaawansowania aż do poziomu, który obecnie możemy obserwować na naszej

14 Antyfideizm należy rozumieć w odniesieniu do pojęcia fideizmu (łac. fides - wiara), czyli poglądu dotyczącego relacji wiary i rozumu, akcentującego rolę wiary w poznaniu ludzkim. Mogą tu wystąpić różne postawy intelektualne, od skrajnego zanegowania rozumu do przekonania o dopełniającej roli czynników pozaracjonalnych w poznaniu umysłowym. W praktyce często występuje jako bezkrytyczne przyjmowanie pewnych treści podawanych za prawdę religijną przez jakiś autorytet. W takim kontekście antyfideizm będzie oznaczał postawę dowartościowującą rolę rozumu w doświadczeniu wiary. „Wiara sama w sobie jest także użyciem rozumu" - twierdzi S. Wszołek (tenże, Racjonalność wiary, Kraków 2003, 11). Postawa antyfideistyczna widzi m.in. zasadność oparcia przekonań religijnych na historycznym uzasadnianiu faktu objawienia Bożego oraz widzi potrzebę krytyczno-refleksyjnej analizy różnych typów poznania (filozoficzno-naukowego i religijnego), umożliwiającej głębsze zrozumienie prawd wiary. W konsekwencji chrześcijaństwo broni racjonalności świata, głosi racjonalność prawd wiary oraz potrzebę ich uzgodnienia z wynikami badań naukowych. Zob. Z. Chlewiński, Fideizm w filozofii, w: Powszechna Encyklopedia Filozofii, t. 3, red. A. Maryniarczyk, Lublin 2002, 427-428; Cz. Bartnik, Fideizm w teologii, w: Powszechna Encyklopedia Filozofii, dz. cyt., 428-429; zob także rozdz. Religia i racjonalność, w: A. Bronk, Podstawy nauk o religii, Lublin 2003, 355-387. 
planecie. Tę prawidłowość, określaną ogólnie jako stopniowy wzrost złożoności organizmów żywych, nazywamy ewolucją życia ${ }^{15}$.

Termin 'ewolucja' nie jest jednoznaczny. Zmieniał się zależnie od rozwoju wiedzy przyrodniczej, metodologicznej oraz filozoficznej refleksji nad nim i współcześnie zależy od obszaru rzeczywistości, do którego jest on odnoszony. W tych różnych kontekstach ewolucję pojmuje się jako wszelkie stopniowe zmiany, postępujące sukcesywnie $\mathrm{w}$ jednokierunkowym procesie, $\mathrm{np}$. od stanu nieuporządkowania do stanu określonego, od stanu niższego do wyższego ${ }^{16}$. W związku z interpretacyjnymi nieporozumieniami w 1959 roku w Chicago zostało przyjęte przez biologów umowne określenie ewolucji: „jako jednokierunkowy, nieodwracalny, przebiegający w czasie proces, który urzeczywistniając się przynosi nowość, różnorodność i wyższe szczeble organizacji. Proces ten zachodzi w każdej sferze świata zjawisk, został jednak najpełniej opisany i zbadany w sferze biologii"17. Proces ten związany jest $\mathrm{z}$ wyjaśnianiem rozwoju wszechświata (kosmogeneza), tworzenia się skorupy ziemskiej (geogeneza), powstania życia (abiogeneza) oraz pochodzenia człowieka (antropogeneza).

15 Por. M. Heller, T. Pabjan, Elementy filozofii przyrody, Kraków 2014, 229.

16 Należy jednocześnie zauważyć, że 'ewolucja' jest terminem podstawowym, od którego pochodzi inny wieloznaczny termin: 'ewolucjonizm'. Oznacza rozmaite poglądy i doktryny (przyrodnicze i filozoficzne) odnoszące się do procesów ewolucyjnych; akceptacja tych ujęć i przypisywana im ranga w bardzo dużym stopniu zależy od przyjętego kryterium uznawania twierdzeń za wiarygodne, od znajomości metod współczesnej nauki oraz od orientacji w aktualnym stanie badań różnych dziedzin nauki. Często w potocznych sformułowaniach stanowi synonim „teorii ewolucji”. Uogólniając, trzeba odróżniać to, że problem ewolucji najczęściej związany jest z przyrodniczą (zwykle darwinowską) teorią ewolucji, zaś ewolucjonizm można określić jako filozoficzny, światopoglądowy czy wręcz ideologiczny korelat przyrodniczej teorii ewolucji. Jako taki stanowi ważną część współczesnej problematyki określanej mianem relacji nauka i wiara. Zob. szerzej J. Zon, Ewolucjonizm, w: Powszechna Encyklopedia Filozofii, t. 3, red. A. Maryniarczyk, Lublin 2003, 335-351; tenże, Ewolucja i ewolucjonizm, w: Filozofia przyrody, (Seria: Dydaktyka filozofii, t. 3), red. S. Janeczek, A. Starościc, D. Dąbek, J. Herda, Lublin 2013, 87-113.

17 Evolution after Darwin, t. III: Issues in evolution, red. S. Tax, Ch. Calender, Chicago Londyn 1960, 107, cyt. za: M. Heller, T. Pabjan, Elementy filozofii przyrody, dz. cyt., 229. 
Przyjmując w punkcie wyjścia fakt biologicznej zmienności organizmów żywych, przyrodnicza teoria ewolucji zmierza do: a) przedstawienia zmienności i rozwoju organizmów jako dokonującego się w czasie procesu historycznego; b) uszeregowania faz rozwojowych poszczególnych gatunków roślin i zwierząt na podstawie danych kopalnych; c) rozpoznania praw rządzących ewolucją oraz sformułowania teorii umożliwiających wytłumaczenie faktu zmienności i rozwoju ${ }^{18}$.

Pierwszą naukową teorią, wyjaśniającą procesy ewolucyjne, była koncepcja Jeana Baptisty de Lamarcka z 1809 r., zwana lamarkizmem lub teorią transmutacji ${ }^{19}$. Natomiast właściwa teoria ewolucji została sformułowana przez Karola Darwina, który ogłosił ją w opublikowanym w 1859 r. dziele $O$ powstawaniu gatunków. Opierając się na długotrwałych badaniach i obserwacjach przyrody, naukowiec ten stwierdził, że istnieją dwie prawidłowości, które są przyczynowym wyjaśnieniem bogactwa gatunków roślin i zwierząt oraz tłumaczą fakt ich zmienności i przystosowań. Są to: 1) walka o byt - polegająca na ciągłej rywalizacji o ograniczone zasoby środowiska oraz 2) dobór naturalny - decydujący o tym, że przeżywają osobniki najlepiej przystosowane do warunków życia $\mathrm{w}$ danym środowisku. Właśnie te dwa mechanizmy, zdaniem Darwina, ukierunkowując ewolucję wszystkich gatunków, decydują o tym, że populacje kolejnych pokoleń dziedziczą cechy najlepiej przystosowanych osobników ${ }^{20}$. Teoria Darwina nie była w stanie w pełni wyjaśnić mechanizmu dziedziczenia cech i zmienności gatunków. Dopiero odkrycia współczesnej genetyki doprowadziły do powstania tzw. syntetycznej teorii ewolucji. Łącząc ze sobą dane różnych nauk biologicznych, paleontologii, ekologii, biogeografii, etologii oraz genetyki molekularnej,

18 Por. S.W. Ślaga, Ewolucjonizm, w: Katolicyzm A-Z, red. Z. Pawlak, Poznań 1997, 117.

19 Chodzi o teorię wyjaśniającą zmienność gatunków. Natomiast sama idea ewolucji pojawia się w rozważaniach filozoficznych już we wczesnej starożytności. Zob. E. McMullin, dz. cyt., 43-56.

20 Por. M. Heller, T. Pabjan, Elementy filozofii przyrody, dz. cyt., 235-238. 
stanowi ona wszechstronną i spójną, chociaż niejednorodną, teorię tłumaczącą przyczynowo fakty i prawidłowości ewolucji, opierającą się na zasadach darwinizmu ${ }^{21}$.

Do podstawowych tez syntetycznej teorii ewolucji zaliczamy stwierdzenie, że:

a. dziedziczenie cech dokonuje się na podstawie praw genetyki;

b. proces dziedziczenia nie jest absolutnie dokładny, w wyniku czego organizmy podlegają zmienności;

c. zmienność organizmów powodowana jest przez mutacje, rekombinacje oraz transfery genów;

d. ograniczone zasoby środowiska powodują, że osobniki zmuszone są do walki o byt;

e. dobór naturalny stanowi czynnik stabilizujący, dzięki czemu usuwane są mutanty o skrajnych cechach;

f. dobór naturalny prowadzi do tego, że przeżywają i rodzą potomstwo osobniki lepiej przystosowane do warunków środowiskowych, co skutkuje utrwaleniem się w populacji cech tych osobników ${ }^{22}$.

Według tej teorii za główne czynniki i mechanizmy przyczynowe procesów ewolucyjnych uznaje się: zmienność genetyczną (mutacje, rekombinacje, transfer genów), dobór naturalny, dryf genetyczny (zmiana częstości występowania danego genu w populacji), bariery izolacyjne (ograniczenie lub zahamowanie przepływu informacji genetycznej między populacjami danego gatunku) - geograficzną, ekologiczną i rozrodczą ${ }^{23}$.

Syntetyczna teoria ewolucji nie powinna wywoływać w świadomości człowieka religijnego ekscytacji podobnych do tych, jakie miały

21 Por. S.W. Ślaga, art. cyt., 118.

22 Por. M. Heller, T. Pabjan, Elementy filozofii przyrody, dz. cyt., 243.

23 Na temat mechanizmów przemian ewolucyjnych świata organizmów żywych toczą się dyskusje, jednak aktualnie standardowym ujęciem jest przedstawiona syntetyczna teoria ewolucji. Por. J. Zon, Ewolucja, w: Powszechna Encyklopedia Filozofii, t. 3, red. A. Maryniarczyk, Lublin 2003, 333. 
miejsce ponad wiek temu. Jest ona dobrze uzasadniona przez różne nauki, zarówno przez paleontologię (chociaż nie odkryto wszystkich „ogniw przejściowych”), jak i przez współczesną genetykę. Stanowi więc uogólnioną teorię integrującą i unifikującą rozmaite dziedziny wiedzy dotyczącej powstania i rozwoju życia na Ziemi.

Jednocześnie ewolucja biologiczna rozpatrywana jest dzisiaj jako logiczny, kolejny etap kosmicznej ewolucji. „Obraz świata, jaki kreśli współczesna kosmologia, jest na wskroś ewolucyjny"24.

Za jedno z ważniejszych osiągnięć współczesnej nauki uważa się dzisiaj skonstruowanie tzw. standardowego modelu kosmologicznego, opisującego najbardziej prawdopodobny scenariusz ewolucji wszechświata. Praktycznie aż do początków XX w. nie istniała żadna ściśle naukowa teoria wszechświata, która dawałaby opis obrazu świata w skali globalnej (jego kosmologiczne tło). Dopiero wraz z rozwojem kosmologii relatywistycznej pojawiła się możliwość najpierw teoretycznego zbudowania, następnie empirycznego potwierdzenia standardowego modelu kosmologicznego ${ }^{25}$. Otóż według tej teorii, kosmiczna epopeja rozpoczyna się około 14 miliardów lat temu od Wielkiego Wybuchu (ang. Big Bang) - tzw. początkowej osobliwości. Hipoteza Wielkiego Wybuchu pojawiła się w 1922 r. w kosmologicznym modelu Aleksandra Friedmana oraz - niezależnie - model

24 M. Heller, Sens życia i sens wszechświata. Studia z teologii współczesnej, Kraków 2015, 165.

25 Kosmologia, ogólnie mówiąc, jest nauką o wszechświecie jako największej możliwej rzeczywistości materialnej. Przez bardzo długi czas podejmowane przez nią zagadnienia były domeną filozofii. Jednakże wraz z rozwojem nowożytnych nauk przyrodniczych, zwłaszcza fizyki i astronomii, wykształciła się nowa dyscyplina naukowa, która „odwołując się do metod matematycznego przyrodoznawstwa, usiłuje sformułować empirycznie testowalną wiedzę o wszechświecie jako całości”. Tak rozumiana kosmologia jest nauką z pogranicza astronomii i fizyki. W formułowaniu i uzasadnianiu swoich tez szeroko korzysta z danych empirycznych ujętych w języku matematycznym. Kosmologią relatywistyczną nazywa się kosmologię budowaną w oparciu o ogólną teorię względności. Zob. J. Turek, Kosmologia, w: Powszechna Encyklopedia Filozoficzna, t. 5, red. A. Maryniarczyk, Lublin 2004, 885-889; M. Heller, Filozofia kosmologii. Wprowadzenie, Kraków 2013. 
ekspandującego (od początkowej osobliwości) wszechświata - odkrył w 1927 r. belgijski ksiądz Georges Lemaître. Do rozwoju tej hipotezy przyczynił się Edwin Hubble - amerykański astronom badający przesunięcie ku czerwieni w widmach galaktyk (prawo Hubble'a, 1929 r.). Jej kolejnym potwierdzeniem stało się odkrycie mikrofalowego promieniowania tła (zwanego też promieniowaniem reliktowym lub szczątkowym), będącego odległym „echem” po wczesnych etapach ewolucji wszechświata, powstałym niedługo po Wielkim Wybuchu. Odkrycie to, dokonane w latach 1964-1965 przez dwóch fizyków Arno Penziasa i Roberta Wilsona, zostało ostatecznie potwierdzone przez badania sond kosmicznych COBE (1991), WMAP (2003) i satelity Planck (2013).

Badane zjawisko przesunięcia ku czerwieni w widmach odległych galaktyk zostało zinterpretowane jako dowód na to, że galaktyki „uciekają" od siebie z rosnącymi prędkościami. Konsekwencją było uznanie, że cały ten proces musiał rozpocząc się od swego rodzaju ogromnej eksplozji obejmującej całą czasoprzestrzeń razem z zawartą $\mathrm{w}$ niej materią. Tak pojawia się intuicyjnie zrozumiałe określenie „Wielkiego Wybuchu”26. Jest ono stosowane zamiennie z technicznym terminem: „początkowa osobliwość. Nazwa ta związana jest z tym, że w "punkcie startu” (metaforycznie mówiąc) wszystkie parametry fizyczne przyjmują wartości osobliwe: czas i objętość dążą do zera, a ciśnienie, temperatura i gęstość - do nieskończoności. To jest „punkt”, w którym pojawia się przestrzeń i zaczyna płynąć czas $(\mathrm{t}=0 \mathrm{~s})$. Aby wyjaśnić zachodzące $\mathrm{w}$ tym momencie procesy fizyczne, nie wystarczy odwołanie się do aktualnie znanych teorii fizycznych, być może dopiero znalezienie kwantowej teorii grawitacji (zbudowanie kwantowej kosmologii) pomoże rozwiązać zagadkę początkowej

26 Na temat historii teorii Wielkiego Wybuchu zob. np. M. Heller, Granice kosmosu i kosmologii, Warszawa 2005. 
osobliwości ${ }^{27}$. Chwila, w której zaczynają obowiązywać znane nam dziś teorie fizyki, nazywa się progiem lub erą Plancka i jej wartość wynosi $\mathrm{t}=10^{-44}$ sekundy po Wielkim Wybuchu.

Dzieje wszechświata to następujące teraz po sobie kolejne etapy obejmujące pięć er kosmicznych: chaotyczną, hadronową, leptonową, radiacyjną i galaktyczną ${ }^{28}$. W bardzo dużym skrócie można powiedzieć, że w niewyobrażalnych ułamkach sekundy, przy spadającej temperaturze i gęstości, pojawiają się cztery oddziaływania fundamentalne: grawitacyjne, elektromagnetyczne, jądrowe silne i jądrowe słabe; istnieją już także kwarki (luźne cząstki elementarne), z których następnie tworzą się hadrony (protony i neutrony) oraz ich antycząstki; przez kilka sekund tworzą się leptony (np. elektrony, neutrina i ich antycząstki), a następnie przez kilka minut zachodzi proces syntezy jąder lekkich pierwiastków, zwłaszcza helu' ${ }^{29}$. Etapem ewolucji kosmicznej, którego długość nie oblicza się w sekundach, ale szacuje się go na około 400 tys. lat, jest era radiacyjna (promienista). To okres oddzielenia się promieniowania od materii, po którym rozpoczyna się trwająca do dzisiaj era galaktyczna. Przez dziesiątki milionów lat tworzą się pierwsze galaktyki oraz zalążki pierwszych gwiazd, wewnątrz których powstają jądra pierwiastków ciężkich. Z czasem niektóre z nich eksplodują jako tzw. supernowe, wyrzucając w przestrzeń kosmiczną nowe pierwiastki. Następnie przez kilka miliardów lat pod wplywem grawitacji powstają nowe gwiazdy z ich własnymi układami planetarnymi. W jednym $z$ takich

27 Zob. szerzej J. Golbiak, Początek Wszechświata w kosmologii kwantowej, w: Filozofia przyrody, dz. cyt., 255-279.

28 Zob. J. Turek, Kosmologia, art. cyt., 888.

29 Jądra najlżejszego pierwiastka - wodoru - to (w przypadku podstawowego izotopu) pojedyncze protony, a zatem jądra te istniały już wcześniej (powstały w erze hadronowej) - zob.: M. Heller, T. Pabjan, Elementy filozofii przyrody, dz. cyt., 182. 
układów pojawia się planeta, na której zaistniały warunki sprzyjające abiogenezie, czyli powstaniu i ewolucji życia ${ }^{30}$.

Przyjmując zatem taką szerszą perspektywę, zauważamy, że początek i ewolucyjny rozwój wszechświata oraz życia na Ziemi, ujmowane jako empiryczne fakty naukowe, domagają się poszukiwania całościowych interpretacji filozoficzno-teologicznych, które przekraczałyby domenę poznania biologicznego i fizycznego. Taka refleksja może stawać się przyczynkiem do krytycznego namysłu człowieka wierzącego nad budowanym światopoglądem.

\section{KREACJONIZM A EWOLUCJA - NIEKTÓRE PYTANIA I PROBLEMY ŚWIATOPOGLĄDU CHRZEŚCIJAŃSKIEGO}

Istnieje z pewnością wiele szczegółowych pytań i problemów rodzących się w spotkaniu rozważanych tutaj „dwóch idei”. Podjęte tutaj tylko wybrane kwestie mają zwrócić uwagę na to, co jest ważne, aby w szczególnego rodzaju dialogu wiary i nauki zaistniała możliwość kształtowania się uniwersalnego, integralnego i antyfideistycznego światopoglądu chrześcijańskiego.

\subsection{ZARYS HISTORYCZNO-TEOLOGICZNEGO KOMENTARZA}

DO BIBLIJNEGO OPISU STWORZENIA

Podstawą i punktem wyjścia wszystkich rozważań związanych z ideą stworzenia jest biblijny opis tego wydarzenia zawarty w dwóch pierwszych rozdziałach Księgi Rodzaju ${ }^{31}$. Ten w istocie niedługi fragment

30 Syntetyczny opis scenariusza standardowego modelu kosmologicznego podaję za M. Heller, T. Pabjan, Elementy filozofii przyrody, dz. cyt., 178-183.

31 Oczywiście poza Księgą Rodzaju istnieje szereg innych ważnych fragmentów w Piśmie Świętym, które w różnych aspektach związane są z ideą stworzenia. Zob. np.: P. Auvray, Stworzenie, w: Słownik Teologii Biblijnej, red. X. Leon-Dufour, tłum. z fr. K. Romaniuk, Poznań 1994, 907-913; B. Poniży, Pojęcie stworzenia w leksyce i argumentowaniu Księgi Mądrości, w: Słowo pojednania. Księga Pamiątkowa z okazji siedemdziesiątych urodzin 
starożytnego tekstu, będący przede wszystkim nośnikiem ważnych prawd teologicznych, stał się źródłem trwających wiele wieków dyskusji, sporów czy wręcz kontrowersji na płaszczyźnie religia (teologia) - nauka. Jak zatem czytać i rozumieć ów biblijny opis?

W aspekcie podejmowanych tutaj zagadnień, wydaje się, że pierwszym krokiem w podejściu do jakiegokolwiek tekstu biblijnego jest uświadomienie sobie, że mamy do czynienia ze starożytnym tekstem literackim, który powstał w konkretnym kontekście historyczno-kulturowym. W związku z tym należy zawsze pamiętać o zasadach interpretacji tekstów biblijnych, które mają wpływ na indywidualne przeżywanie wiary, jak i na życie całej wspólnoty Kościoła ${ }^{32}$. Odkrycie właściwego przesłania tekstu biblijnego, czyli interpretacji zgodnej z intencją autora, wymaga również odwołania się do wielu nauk pomocniczych biblistyki, takich jak archeologia i geografia biblijna, historia i filologia starożytna, literatura porównawcza itp.

W związku z tym wiemy dzisiaj, że poemat o stworzeniu, zwany Heksaemeronem ${ }^{33}$ (Rdz 1,1-2,4a), pochodzi z okresu niewoli babiloń-

Księdza Michała Czajkowskiego, red. J. Warzecha, Warszawa 2004, 82-96; M. Baranowski, „Chwała Pana napełnia Jego dzieło” (Syr 42,16b). Wysławianie Stwórcy i dzieła stworzenia w psalmach i księgach mądrościowych, Lumen vitae 1(2000), 137-151; K. Romaniuk, Zagadnienie naturalnego poznania Boga według Rz 1,18-33, Rocznik Teologii Katolickiej 24(1977)1, 59-68; M. Gołębiewski, Idea stworzenia w Biblii Hebrajskiej i teologii żydowskiej, w: Dzieci jednego Boga. Praca zbiorowa uczestników seminarium naukowego w Spertus College of Judaica w Chicago (1989), red. W. Chrostowski, Warszawa 1991, 53-71; J. Kosek, Model budowy świata według Księgi Hioba [Hi 26,5-13], w: Z badań nad Bibliq̨, red. T. Jelonek, Kraków 2003, 189-218; E. Świerczek, Poznanie Boga według Pisma Świętego. Czy Mdr 13,1-9 i Rz 1,18-23 oraz późna tradycja żydowska uzupełniają ogólną naukę biblijną na temat poznania Boga?, Przegląd Kalwaryjski 11-12(2007-2008), 25-47; M.V. Fabbri, Creazione e salvezza nel libro della Sapienza. Esegesi di Sap 1,13-15, Roma 1998.

3223 kwietnia 1993 r. Jan Paweł II ogłosił dokument Papieskiej Komisji Biblijnej, który porządkuje i wyjaśnia te kwestie. Zob. Interpretacja Biblii w Kościele. Przemówienie Ojca Świętego Jana Pawła II oraz Dokument Papieskiej Komisji Biblijnej, Poznań 1994.

33 W taki sposób po raz pierwszy biblijny opis stworzenia określił Filon z Aleksandrii (od gr. hexa hemeron - sześć dni). 
skiej, a redakcja Księgi Rodzaju nastąpiła dopiero po powrocie Izraela z niewoli (VI w. przed Chrystusem) ${ }^{34}$. Powstaje więc w kontekście poważnego kryzysu politycznego i religijnego związanego ze zburzeniem Jerozolimy przez Nabuchodonozora II (587 r. p.n.e), deportacją elit izraelskich do Babilonu oraz zderzenia się z obcą, politeistyczną kulturą. Zatem jest to próba zrozumienia i zinterpretowania w kategoriach teologicznych aktualnych doświadczeń historycznych Narodu Wybranego (dlaczego wygnanie i prześladowanie?). Pierwszym celem tego opisu jest pocieszenie, dodanie otuchy, budzenie nadziei i wiary. Bóg Jahwe nie zapomina o swoim ludzie. Jest Bogiem wszystkich narodów, ponieważ jest Stwórcą wszechświata. W związku z tym nawet Babilończycy stają się tylko narzędziami w Jego ręku ${ }^{35}$. Inną bardzo ważną kwestią, która zrodziła się w kontekście zburzenia świątyni jerozolimskiej i niewoli, jest potrzeba teologicznego zinterpretowania i uzasadnienia liturgicznych przepisów związanych z kultem religijnym (np. świętowanie szabatu).

$Z$ całą pewnością więc biblijny opis stworzenia nie jest naukowym opisem kosmologicznym (choćby tylko historycznie wziętym). Kosmologia jako nauka o wszechświecie w jego globalnej skali nie była podstawowym zainteresowaniem starożytnych Hebrajczyków. Zatem i sama Biblia w rzeczywistości nie zawiera żadnej kosmologii ${ }^{36}$.

Nie ma dzisiaj wątpliwości co do tego, że opis stworzenia jest poematem, czyli utworem poetyckim zbudowanym analogicznie do innych pieśni biblijnych albo znanych z tradycji pozabiblijnej, takich jak babiloński poemat Enuma Elisz lub sumeryjski poemat

34 Obszerną bibliografię dotyczącą powstania i egzegezy Księgi Rodzaju zobacz w komentarzach: T. Brzegowy, Pięcioksiąg Mojżesza. Wprowadzenie i egzegeza Księgi Rodzaju 1 - 11, Tarnów 2002; S. Łach, Księga Rodzaju. Wstęp, przekład z oryginału, komentarz, Poznań 1962.

35 Por. M. Heller, T. Pabjan, Stworzenie i początek wszechświata. Teologia - Filozofia Kosmologia, Kraków 2014, 13-37.

36 Por. N.M. Wildiers, Obraz świata a teologia. Od średniowiecza do dzisiaj, tłum. z niem. J. Doktór, Warszawa 1985, 28-29. 
o Gilgameszu ${ }^{37}$. Intencją autora natchnionego nie było przekazywanie wiedzy z zakresu przyrodoznawstwa, ale określone przesłanie teologiczne, które można ująć w czterech głównych zagadnieniach: natura Boga, prymat człowieka, pierwotne dobro stworzeń i obowiązek szabatu ${ }^{38}$.

Spróbujmy krótko podkreślić tylko jeden $\mathrm{z}$ aspektów teologii stworzenia, który bezpośrednio dotyczy tytułowej tematyki. Cały opis jednoznacznie wskazuje na fundamentalną prawdę - z punktu widzenia religijnej doktryny chrześcijaństwa - że wszystko, co istnieje (cały wszechświat), pochodzi od Boga. Heksaemeron ukazuje stworzenie jako akt natychmiastowy - na rozkaz Boga. Dokonuje się on z łatwością, bez jakiejś nieokreślonej walki. Widać tu wyraźną polemikę ze starożytnymi kosmogoniami, w których początkiem wszystkiego jest pierwotna walka między bóstwami albo wszechświat jest emanacjąjakiegoś bóstwa. Tekst biblijny w sposób jednoznaczny ukazuje prawdę, że Bóg Stwórca jest wszechmocny i jedyny. Nie musi więc z nikim walczyć, a stworzenie nie jest częścią Boga i nie posiada boskiej natury w wyniku emanacji. Nie należy także sądzić, by Stwórca tylko „tworzył” świat z jakiegoś przedwiecznego chaosu. Księga Rodzaju nie zawiera w sobie takich idei. Co więcej, opis ten jest polemiczną odpowiedzią na takie pogańskie koncepcje kosmologiczne ${ }^{39}$. Podobnie polemikę z pogańskimi kosmogoniami widać w demitologizowaniu świata przyrody. Wszystkie ciała niebieskie otaczane boską czcią, jak np. Słońce, Księżyc oraz każdy inny byt,

37 Por. S. Grzybek, Teologia kapłańskiego opisu stworzenia świata (Rdz 1,1 - 2,4a), w: Początek świata - Biblia a nauka, red. M. Heller, M. Drożdż, Tarnów 1998, 36-41.

38 O bogactwie i wadze teologicznego przesłania Heksaemeronu można przekonać się czytając i rozważając duszpasterski komentarz do ksiąg Starego Testamentu Jana Pawła II. Nie jest to ściśle naukowa, egzegetyczna praca. Jednak, wykorzystując całe dziedzictwo nauk biblijnych, papież ukazuje m.in. Księgę Rodzaju jako wielki skarbiec Bożej mądrości dotyczącej życia człowieka. Zob. Jan Paweł II, Komentarz do Ksig̨g Starego Testamentu, Kraków 2012.

39 Por. T. Brzegowy, Kosmologia (kosmogonia) biblijna, w: Duch i Oblubienica mówią: Przyjdź, red. W. Chrostowski, Warszawa 2001, 80. 
są tylko czysto naturalnymi stworzeniami, które na mocy stwórczej woli Boga mają służyć dobru człowieka. Sam Stwórca nadaje im imiona, co oznacza określenie ich niezmiennej natury.

Powyższa synteza jednego $\mathrm{z}$ aspektów teologicznego przesłania poematu o stworzeniu przekonuje o tym, co zostało już powiedziane, że Heksaemeron nie jest naukowym opisem informującym o początkach i budowie wszechświata. Rozpoznawanie prawdy tego opisu pozwala na budowanie dojrzałego światopoglądu chrześcijańskiego, którego ważną cechą będzie antyfideizm. Człowiek wierzący (chrześcijanin), pozostając otwartym na możliwość krytycznego, racjonalnego wyjaśniania i uzasadniania (chociaż nie oznacza to dowodzenia) pewnych prawd wiary chrześcijańskiej, będzie m.in. unikał fundamentalistycznej interpretacji Pisma Świętego, co w powyższym kontekście szczególnie odnosi się do opisu stworzenia z Księgi Rodzaju ${ }^{40}$.

$\mathrm{Na}$ koniec warto przytoczyć bardzo ważną uwagę św. Augustyna z Hippony (IV/V w.), Ojca Kościoła, w którego myśli znalazła najpełniejszy wyraz teologiczna refleksja nad dziełem stworzenia, zapoczątkowana już przez samych autorów Nowego Testamentu. Otóż w dziele De Genesi ad Litteram ${ }^{41}$, stanowiącym studium dyskutowanego tutaj tekstu z Księgi Rodzaju, a ukończonym po czternastu latach pracy w 415 r., podkreśla, że egzegeza przy poszukiwaniu interpretacji danego fragmentu biblijnego musi brać pod uwagę wnioski płynące z osiągnięć i rozważań poszczególnych nauk. Ilekroć zatem pojawia się konflikt między dosłownym odczytaniem jakiegoś fragmentu Pisma Świętego a dobrze ustaloną prawdą dotyczącą przyrody, należy poddać tekst biblijny reinterpretacji metaforycznej. W poszukiwaniu prawdy nie powinniśmy walczyć o własną interpretację, lecz

40 Krytyczne uwagi na temat fundamentalistycznego odczytywania Pisma Świętego zobacz dokument Papieskiej Komisji Biblijnej - Interpretacja Biblii w Kościele, dz. cyt.

41 Polski przekład: Przeciwko Manichejczykom komentarz do Księgi Rodzaju, w: Pisma przeciw Manichejczykom, (seria: Pisma Starochrześcijańskich Pisarzy, t. XXV), tłum. z łac. J. Sulowski, Warszawa 1980. 
o naukę Pisma Świętego. Rzecz w tym, abyśmy nie naginali znaczenia Biblii do naszych interpretacji, ale by nasze interpretacje wynikały z prawdy Pisma Świętego ${ }^{42}$. Uwzględnienie opinii św. Augustyna w pewnym sensie chroni teologię chrześcijańską przed wpadnięciem w pułapkę światopoglądu przednaukowego. Jego stanowisko, które przyjął i pogłębił św. Tomasz z Akwinu, z pewnością istotnie przyczyniło się do rozwoju kosmologii średniowiecznej od XIII w. oraz rozwiązywania sporów w relacji nauka i religia ${ }^{43}$.

\subsection{KOSMOLOGICZNE TŁO OBRAZU ŚWIATA}

Przytoczona wyżej opinia św. Augustyna, aby przy interpretacji niektórych fragmentów Pisma Świętego brać pod uwagę wyniki poszczególnych nauk, może być dobrą okazją do zastanowienia się nad innymi ciekawymi i jednocześnie niełatwymi problemami chrześcijańskiego światopoglądu. Jest to również okazja do przemyślenia kolejnych jego charakterystycznych właściwości, mianowicie uniwersalizmu i integralizmu.

Uniwersalizm oznacza przede wszystkim to, że światopogląd, jak pisze M. Lubański, ,jest dla wszystkich ludzi i kultur, po wszystkie czasy, przyswaja każdą prawdę, żadnej nie odrzucając"44. Natomiast integralizm to niepomijanie żadnej części i żadnego aspektu w patrzeniu na otaczający świat, co pozwala harmonijnie ujmować rzeczywistość, a więc człowieka, świat, Boga oraz chroni jednostkę przed skrajnymi interpretacjami.

Tak rozumiany uniwersalizm w perspektywie chrześcijańskiej wiary (teologii) jest zrozumiały. Uogólniając, możemy powiedzieć, że objawione prawdy pozostają niezmiennie te same niezależnie od

42 Por. T. van Bavel, The Creator and the Integrity of Creation in the Fathers of the Church, Augustinian Studies 21(1990), 1-33.

43 Por. A. McGrath, Nauka i religia, tłum. z ang. M. Chojnacki, Kraków 2009, 15.

44 M. Lubański, art. cyt., 363. 
czasu, miejsca czy kultury. Jednak wiara religijna (teologia) potrzebuje języka, za pomocą którego będzie mogła adekwatnie wyrazić treści zawarte w Objawieniu. Z taką szczególną sytuacją wspólnota chrześcijańska zmagała się już w początkach głoszenia Ewangelii, kiedy uczniowie Jezusa, chcąc ogłosić Jego naukę, musieli sięgnąć do zrozumiałego języka ówczesnej kultury (języka greckiego) oraz poddać Objawienie niełatwym zabiegom interpretacyjnym. Trzeba zauważyć jednak, że każda epoka historyczna odznacza się pewnymi trendami kulturowymi, społecznymi i naukowymi, które podlegają zmianom. Trudno więc mówić o raz na zawsze ustalonym, uniwersalnym i powszechnym „kodzie językowym”, który przekazywałby ważne prawdy. Czy uniwersalność światopoglądu chrześcijańskiego w tym kontekście nie powinna być rozumiana również jako otwartość wiary (teologii) na krytyczne dostosowywanie swojego przekazu do tych przemian? Dotyczy to przede wszystkim ewolucji szeroko pojętej kultury i obrazu świata obowiązującego w danej epoce. To właśnie on w pewien sposób wpływa na język i kształtuje właściwy dla danej epoki styl myślenia i metodę działania. Oczywiście teologia nie powinna wiązać się w sposób ścisły z żadnym konkretnym obrazem ze względu na jego zmienność, ale nie może całkowicie pominąć czy wręcz zignorować jakiegokolwiek obrazu świata. Bardzo mocno podkreśla to M. Heller stwierdzając, że: „Jeśli prawdy teologiczne mają być zrozumiałe dla człowieka żyjącego w danej epoce, to nie mogą być całkowicie oderwane od obrazu świata, który stanowi kulturowe tło epoki" 45 .

Szczególnie wyraźnie ujawnia się to w przypadku prawdy teologicznej dotyczącej stworzenia świata przez Boga. Prowadzi ona bowiem nieuchronnie do pytań i zagadnień z zakresu współczesnych nauk (biologii, fizyki, astronomii, kosmologii) o początek i ewolucję całego uniwersum. Budowanie uniwersalnego oraz integralnego światopoglądu chrześcijańskiego musi zmierzyć się z odpowiedziami

45 M. Heller, T. Pabjan, Stworzenie i początek wszechświata, dz. cyt., 90. 
na te problemy także poza kontekstem teologicznym. Nie można więc uniknąć odwołania się do aktualnego obrazu świata. A ten z kolei zawsze do pewnego stopnia - a współcześnie widać to bardzo wyraźnie - jest obrazem "naukowym”, tzn. tworzą go elementy pochodzące $z$ teorii lub modeli naukowych aktualnie obowiązujących. Ważnym aspektem tego obrazu jest kosmologiczne tło, które można by określić jako pewnego rodzaju „arenę, na której »dzieje się" historia całego wszechświata"46. Dzięki rozwojowi kosmologii relatywistycznej w XX w. i skonstruowaniu tzw. standardowego modelu kosmologicznego, który jest konsekwencją dobrze potwierdzonych teorii naukowych, możemy zrozumieć, jak w rzeczywistości wygląda ów „globalny” aspekt obrazu świata ${ }^{47}$.

Dla chrześcijańskiej teologii stworzenia, zainteresowanej kosmologicznym tłem przyrodniczego obrazu świata, zrodziło się pytanie: czy Wielki Wybuch, który rozpoczął ewolucję Wszechświata można, z perspektywy teologicznej, w prosty sposób utożsamić z aktem stworzenia świata przez Boga? Interesujące jest również to, że jednocześnie pojęcie 'stworzenia' zaczęło się pojawiać w ściśle naukowych dyskusjach dotyczących modeli wszechświata powstających na gruncie kosmologii relatywistycznej ${ }^{48}$. Wydaje się, że integralizm i uniwersalizm światopoglądu chrześcijańskiego wymaga namysłu nad prawdą o stworzeniu świata przez Boga, biorąc pod uwagę kontekst „kosmologicznego tła” określonego przez standardowy model kosmologiczny.

46 Tamże.

47 Zob. M. Tempczyk, Przyrodniczy obraz świata - standardowy model ewolucji Wszechświata, w: Filozofia przyrody, dz. cyt., 231-254.

48 Por. M. Heller, T. Pabjan, Stworzenie i początek wszechświata, dz. cyt., 92. 
3.3. KŁOPOTY WOKÓŁ WIELKIEGO WYBUCHU

Analizując zagadnienie tzw. początkowej osobliwości, w naturalny sposób stajemy wobec pytania o początek świata i bardzo łatwo przechodzimy do wniosków o charakterze filozoficznym i światopoglądowym. Nawet naukowcy zajmujący się budowaniem modeli kosmologicznych podzielili się w sporze o interpretację początkowej osobliwości. Jedni utożsamiają Wielki Wybuch ze stworzeniem świata przez Boga, drudzy uważają go za początek świata lub początek jego obecnej fazy ewolucyjnej, lecz unikają interpretacji teologicznej, inni zaś $\mathrm{z}$ różnych powodów są przeciwni szukaniu genezy świata w początkowej osobliwości ${ }^{49}$. Brak tutaj miejsca na referowanie tak licznych aspektów tego problemu. Należy natomiast powiedzieć, że nie widać przekonujących argumentów, które mogłyby zakończyć dyskusję na temat możliwości utożsamienia Wielkiego Wybuchu z początkiem świata. Być może sformułowanie teorii kwantowej grawitacji - połączenia mechaniki kwantowej z ogólną teorią względności - pozwoli w przyszłości rozstrzygnąć ten spór i odpowiedzieć na pytanie: czy Wielki Wybuch rzeczywiście rozpoczyna historię Wszechświata.

Nie można pominąć także faktu, że podejmowane są próby budowania modeli kosmologicznych, w których początkowa osobliwość (Wielki Wybuch) nie występuje. Bardzo znanym przykładem (ujawniającym również motywacje światopoglądowe) jest model Hawkinga-Hartle’a, który w zamierzeniu Hawkinga miałby dowieść,

49 Na atmosferę sporu wpłynęła także jedna z oficjalnych wypowiedzi papieża Piusa XII w 1951 roku, który potraktował teorię Wielkiego Wybuchu jako argument za stworzeniem świata przez Boga czy wręcz jako dowód za istnieniem Boga. Zob. Pius XII, Dowody istnienia Boga w świetle nowoczesnej nauki, w: Dokumenty Nauki Kościoła, seria III, t. 2, red. T. Dobrowolski, Londyn 1952. Podaję za: T. Pabjan, Czy nauka dowodzi istnienia Boga? Naukowa apologetyka Piusa XII, Studia Philosophiae Christianae 45(2009)2, 277-294. Zob. tam szerzej na temat interpretacji, jaką Pius XII nadawał teorii Wielkiego Wybuchu. 
że Wszechświat powstał samoistnie za pomocą praw fizyki ${ }^{50}$. Jednakże taki model zakłada najpierw istnienie praw fizyki, a zatem nie rozwiązuje problemu początku świata, ale zamienia go na problem początku (pochodzenia) praw fizyki ${ }^{51}$.

Przy budowaniu chrześcijańskiego światopoglądu (w podejmowanym tutaj aspekcie) może wystąpić bardzo subtelna „pokusa” utożsamienia Wielkiego Wybuchu z momentem, w którym Bóg stworzył świat (np. E.T. Whittaker, Pius XII). Niestety przypomina to dziedzictwo fizyko-teologii z XVII wieku. Wówczas zrodził się taki styl myślenia, w którym teologia i nauki przyrodnicze bardzo ściśle łączyły się ze sobą, kładąc fundament pod wiarę religijną, która - jak słusznie zauważa Michał Heller - była „łatwa”: „(...) istnienie Boga stanowiło niemal prawdę naukową, świat bez Stwórcy wydawał się tak samo niemożliwy, jak zegarek bez swego konstruktora" 52 . Jednak wraz z rozwojem nauk przyrodniczych, Bóg zaczął być stopniowo usuwany z takiego „naukowego obrazu świata”. Świat wyjaśniał się sam przez siebie bez konieczności uciekania się do „hipotezy Boga”.

Abstrahując od światopoglądowych motywacji Hawkinga, jego model kosmologiczny może być dobrą ilustracją próby pokonywania przez naukę napotykanych niejasności. Bowiem początkowa osobliwość jest raczej ciągle oznaką naszej niewiedzy i braku odpowiedniej teorii fizycznej (kwantowej teorii grawitacji), która wyjaśniałaby sam moment Wielkiego Wybuchu (o ile w ogóle miał miejsce). Utożsamienie zatem „kosmicznego zdarzenia” z aktem stworzenia świata przez Boga jest raczej formą uproszczonego „wyjaśnienia” świata

50 Jest to najbardziej znany przykład, ponieważ stanowi pewną podstawę dobrze spopularyzowanej kosmologii Hawkinga, który twierdzi, że zbudował koncepcję Wszechświata samowystarczalnego ukazującego kosmogenezę ex nihilo - zob. S.W. Hawking, Krótka historia czasu. Od wielkiego wybuchu do czarnych dziur, tłum. z ang. P. Amsterdamski, [Poznań] 2015; S.W. Hawking, L. Mlodinov, Jeszcze krótsza historia czasu, tłum. J. Bieroń, [Poznań] 2007. Koncepcja Hawkinga niesie ze sobą wiele trudności natury filozoficznej oraz z obszaru metodologii nauk przyrodniczych - zob. J. Golbiak, art. cyt., 275.

51 Por. M. Heller, T. Pabjan, Elementy filozofii przyrody, dz. cyt., 189.

52 M. Heller, J. Życiński, Dylematy ewolucji, Kraków 2016, 195. 
przyrody, którą współcześnie ironicznie nazywa się metodą „Boga od zapychania dziur" (ang. God of the gaps). Jednocześnie jest to błąd o charakterze metodologicznym. Zadaniem nauki jest wyjaśnianie świata przyrody - zjawisk i procesów w nim zachodzących - za pomocą innych zjawisk i procesów pochodzących ze świata przyrody. Postulat ten określa się mianem naturalizmu metodologicznego. Stanowi on założenie związane $z$ metodą naukową i nie rozstrzyga niczego na temat ontycznej struktury świata. Nie pozwala więc na przyjęcie hipotezy Boga przy wyjaśnianiu świata przyrody, lecz równocześnie nie domaga się zaprzeczenia istnienia czegokolwiek poza światem fizycznym (byłby to wówczas naturalizm ontologiczny).

Aktualnie we współczesnej kosmologii Wielki Wybuch rozpatrywany jest nie tyle jako początek wszechświata, ile jako początek obecnej ery lub obecnej fazy ewolucji wszechświata. Kosmologia jest więc neutralna wobec zagadnienia stworzenia świata przez Boga. Niezależnie od tego, jakie będą w przyszłości wyniki poszukiwań kwantowej teorii grawitacji - czy dowiedzie, że początkowa osobliwość nie jest absolutnym początkiem wszechświata, ale poprzedza ją wiele innych faz kosmicznej ewolucji - nie zmienia to niczego $\mathrm{w}$ teologicznej doktrynie o stworzeniu ${ }^{53}$. Ona bowiem, otwierając filozoficzno-teologiczną perspektywę - mówiąc słowami Józefa Życińskiego - wypełnia naturalną potrzebę intelektualną człowieka, którą jest poszukiwanie całościowych interpretacji przekraczających płaszczyznę poznania biologii czy fizyki, ,dostarczając odpowiedzi na najgłębsze pytania, zaliczane do tzw. Wielkich Pytań Metafizyki”54.

\section{PYTANIA METAFIZYCZNE... ZAMIAST ZAKOŃCZENIA}

Metoda empiryczna, oczywista dla nauk przyrodniczych, ze swej natury związana jest ze „światem materialnym”. Wyprowadzane

53 Por. M. Heller, T. Pabjan, Stworzenie i początek wszechświata, dz. cyt., 101-110.

54 M. Heller, J. Życiński, Dylematy ewolucji, dz. cyt., 23. 
wnioski oraz formułowane twierdzenia przy wyjaśnianiu wszechświata, w sposób automatyczny wyłączają wszystko to, co wymyka się takiej metodzie. Badając i analizując taką metodą zjawiska przyrody, pytamy o ich racje i w odpowiedzi wskazujemy na najbliższe, cząstkowe przyczyny istnienia danych bytów czy zjawisk. Często dzisiaj w niezwykle bogaty sposób pozwala ona udzielić odpowiedzi na pytania o to, jak rzeczy powstają, jak się rozwijają i dzięki czemu, jako istniejące, działają. Heller określa to ewolucyjną metodą badania świata, w której „ciągi racji i następstw układają się w łańcuchy, które (...) można uważać za ewolucyjne, chociaż w znacznie szerszym znaczeniu niż to się czyni na terenie biologii. Pomiędzy kolejnymi ogniwami łańcuchów nie musi zachodzić związek genetyczny (...); może to być jakakolwiek relacja wyjaśniania jednego zjawiska przez inne, dopuszczalna przez metodę naukową"55.

Inną perspektywę wyjaśniania świata przynosi refleksja filozoficzno-teologiczna. Metafizyka szuka odpowiedzi na pytanie, dzięki czemu ostatecznie rzeczy istnieją; dlaczego działają i do jakiego celu ostatecznie zdążają. Są to pytania o ostateczną rację istnienia całego świata. Analogicznie wygląda to z punktu widzenia teologii. „Dla teologa wyjaśnić świat to usprawiedliwić jego istnienie", stwierdza Heller i dodaje: ,jedynym teologicznym usprawiedliwieniem istnienia świata jest akt stwórczy"56. Takiego usprawiedliwienia domaga się wszystko, co jest przygodne, tzn. taki byt, który może istnieć lub nie istnieć, istnienie nie należy do jego istoty; nie ma on racji istnienia w sobie samym. Skoro jednak istnieje, fakt ten domaga się racjonalnego usprawiedliwienia. Do tej kategorii należą również łańcuchy ewolucyjne, które służą naukom empirycznym do wyjaśnienia świata.

W rzeczywistości to właśnie akcentuje prawda o stworzeniu świata przez Boga. Pogłębione zrozumienie tego zawdzięczamy interpretacji

55 Tamże, 179.

56 Tamże. Myśl ta jest szczególnie analizowana w książce M. Heller, Usprawiedliwienie Wszechświata, Kraków 1984. 
św. Tomasza z Akwinu, który akt stwarzania ukazuje przede wszystkim jako „powoływanie pierwszych relacji”; konstytuowanie się samej zależności, czyli relacji bytu stworzonego od Stwórcy, dzięki któremu on zaistniał ${ }^{57}$. W ten sposób uświadamiamy sobie, że idea stworzenia jest czymś radykalnie głębszym niż problem początku świata. Św. Tomasz, rozważając powyższe zagadnienia, wykazał, że z filozoficznego punktu widzenia możliwe jest odwieczne istnienie świata (a więc świata bez początku), który i tak byłby stwarzany przez Boga. Bowiem zależność w istnieniu od Stwórcy, a nie posiadanie początku jest istotą aktu stworzenia. Oznaczałoby to, że Bóg jest przyczyną sprawczą, która - istniejąc poza czasem - poprzedza świat w sensie logicznym, ale nie w sensie czasowym ${ }^{58}$.

Reasumując powyższe rozważania, należy stwierdzić, że całościowe wyjaśnianie rzeczywistości to nic innego jak próba ujmowania jej w dwóch perspektywach. Pierwsza - to naturalne łańcuchy przyczynowo-skutkowe ze wszystkimi ich trudnościami i wciąż nierozwiązanymi problemami. Jest to domena nauk przyrodniczych z właściwymi im metodami. Druga - to sprawa przygodności, czyli usprawiedliwienia faktu samego istnienia tego łańcucha przyczynowo-skutkowego. To jest kwestia filozoficzno-teologicznego myślenia. Mądrość leży w umiejętnym łączeniu tych dwóch aspektów dotyczących jednej rzeczywistości. W tym kontekście pomocne może być stanowisko Hellera, który przekonuje, że „przyczynowość Boga nie jest przyczynowością rzemieślnika, który wytwarza nową rzecz i poprawia ją w razie potrzeby, lecz przyczynowością Stwórcy, który dla swojego stworzenia jest nieustannym źródłem istnienia. Istnienie, dawane przez Boga swojemu stworzeniu, nie tylko sprawia, że ono

57 Zob. szerzej na temat tego zagadnienia A. Maryniarczyk, Creatio ex nihilo, w: Powszechna Encyklopedia Filozofii, t. 2, red. A. Maryniarczyk, Lublin 2001, 306-318.

58 Zob. Tomasz z Akwinu, O wieczności świata, w: Tomasz z Akwinu, Dzieła wybrane, tłum. z łac. J. Salij, Poznań 1984, 275-281. Zob. także wyjaśnienie tego zagadnienia M. Heller, T. Pabjan, Stworzenie i początek wszechświata, dz. cyt., 78-88. 
jest, lecz że jest tym, czym jest, i że działa tak, jak działa"59. Innymi słowy oznacza to, że ewolucyjne ciągi przyczyn i skutków to ciągi przyczyn narzędnych, które istnienie i działanie zawdzięczają przyczynie głównej, czyli Bogu. Bóg działa przez nie, ale w ich wnętrzu, przez ich „naturalną przyczynowość”. W ten sposób uznając fakt, że Bóg jest bezpośrednią przyczyną wszystkiego, nie niszczymy „naturalnej przyczynowości" - przekonuje Heller. Nie ma więc potrzeby uciekać się do nadzwyczajnych ingerencji Boga i rozrywać naturalny łańcuch przyczynowo-skutkowy, aby wyjaśnić jakiś trudny, przełomowy moment historii ewolucji Wszechświata (np. powstanie życia i człowieka).

$\mathrm{Na}$ koniec warto zastanowić się jeszcze nad potrzebą i wartością pytań o usprawiedliwienie Wszechświata. Otóż usuwanie problemów metafizycznych z obszaru naszej kultury, a nauka stanowi przecież jej bardzo ważną część, prowadzi w rezultacie do rozszczepienia i fragmentaryzacji rzeczywistości oraz kryzysu duchowości. Każdy kryzys kultury to w jakimś stopniu choroba ducha, która między innymi polega na tym, że nie podejmuje się już dawnych pytań metafizycznych, lecz zbyt pochopnie zakłada, że nic one nie znaczą. Pozytywistyczne, a później postmodernistyczne próby deprecjonowania i usuwania metafizyki miały przekonać człowieka nie tylko o jej niemożliwości, ale również o braku potrzeby. Czy jednak możemy zrezygnować z tego, że „świat jest”?60

Usuwanie czy redukowanie tych pytań jest zawsze wbrew naturze człowieka. Nie można od nich uciekać, bowiem zadaje je nasza własna natura i niczym echo powtarza je cały kosmos. Okazuje się dzisiaj, że sam opis „fenomenów” już nam nie wystarcza, aby zrozumieć świat oraz własne istnienie. Nie chodzi oczywiście o to, aby teraz zagadnienia metafizyczne uczynić przedmiotem nauk ścisłych ani tym bardziej nie chodzi o upraszczające „wciskanie” działania

59 M. Heller, J. Życiński, Dylematy ewolucji, dz. cyt., 181.

60 Inspiracją do poniższych refleksji stała się dla mnie książka: M. Szulakiewicz, Poszukiwania metafizyczne, Toruń 2014. 
Boga jako bezpośredniej przyczyny tłumaczącej fakty stwierdzane w naukowym badaniu świata. Wydaje się - i trzeba to podkreślać że nauka po prostu nie powinna i nie wolno jej a priori zamykać współczesnego człowieka na metafizyczne pytania, uznając je za przestarzałe, przezwyciężone i niepotrzebne. $Z$ drugiej strony, integralne oraz antyfideistyczne myślenie religijne, szanujące prawa rozumu kierującego naukami przyrodniczymi, otwiera przestrzeń współczesnej kultury na „coś więcej”.

Świadomość tej „drugiej” perspektywy w odkrywaniu rzeczywistości sprawia, że świat przestaje być bytem absolutnym - w tym w znaczeniu, że wszystko się wyjaśnia przez „tu i teraz” (w jakimś sensie skończony ciąg rzeczy materialnych) - a dla człowieka otwiera się horyzont nieskończoności, który przynosi świadomość wartości i sensu' ${ }^{61}$ Jeśli tego zaczyna brakować, to sam „świat fizyczno-zmysłowy ubożeje i przestaje tworzyć podniety do życia lub tworzy podniety fałszywe, skierowane przeciwko samemu życiu"62.

Zdobywanie dojrzałej postawy wobec całej rzeczywistości, dającej człowiekowi ogólne jej ujęcie, to trudne i odpowiedzialne zadanie. Staje się szczególnym wyzwaniem tak dla ludzi nauki, jak i dla ludzi religijnych, gdy spotykają się ze sobą dwie wielkie idee: stworzenie i ewolucja. Jak się wydaje, jest to nieuchronnie wpisane w drogę rozwoju człowieka. Aby takie spotkanie mogło być ubogacające, potrzebna jest atmosfera dialogu, pomagająca w poszukiwaniu prawdy ${ }^{63}$.

Poznanie źródeł światopoglądu chrześcijańskiego, zrozumienie złożoności wszystkich elementów, które na niego się składają (m.in. historyczno-kulturowych uwarunkowań form, w jakich dociera do nas Boże Objawienie), z pewnością może pomóc w procesie formowania całościowego ujęcia ludzkich spraw. Fundamentem, na którym

61 Por. tamże, 33.

62 Tamże, 30.

63 Por. A. Adamski, Ciągła potrzeba dialogu filozofii z teologią na przykładzie Sprawy Galileusza, w: Człowiek z przełomu wieków w refleksji filozofii dialogu, red. J. Baniak, Poznań 2002, 309-319. 
należy się oprzeć, jest krytyczna postawa umysłu, który, stojąc na twardym gruncie faktów, jednocześnie nie pomija a priori żadnych części rzeczywistości. Dojrzały światopogląd człowieka religijnego może stać się świadectwem, że duch nauki i etyka poszukiwania prawdy są do pogodzenia $\mathrm{Z}$ wiarą chrześcijańską ${ }^{64}$.

\section{BIBLIOGRAFIA}

Adamski A., Ciagta potrzeba dialogu filozofii z teologia na przyktadzie Sprawy Galileusza, w: Cztowiek z przetomu wieków w refleksji filozofii dialogu, red. J. Baniak, Uniwersytet im. Adama Mickiewicza w Poznaniu. Wydział Teologiczny, Poznań 2002, 309-319.

Arystoteles, Metafizyka, tłum. z gr. K. Leśniak, PWN, Warszawa 1983.

Augustyn św., Przeciwko Manichejczykom komentarz do Ksiegi Rodzaju, w: Pisma przeciw Manichejczykom, (seria: Pisma Starochrześcijańskich Pisarzy, t. XXV), tłum. z łac. J. Sulowski, ATK, Warszawa 1980.

Auvray P., Stworzenie, w: Stownik Teologii Biblijnej, red. X. Leon-Dufour, tłum. z fr. K. Romaniuk, Pallotinum, Poznań 1994, 907-913.

Baranowski M., "Chwata Pana napetnia Jego dzieto” (Syr 42,16b). Wystawianie Stwórcy i dzieta stworzenia w psalmach i ksiegach madrościowych, Lumen Vitae 1(2000), 137-151.

Bartnik Cz., Fideizm wteologii, w: Powszechna Encyklopedia Filozofii, t. 3, red. A. Maryniarczyk, Polskie Towarzystwo Tomasza z Akwinu, Lublin 2002, 428-429.

Bavel T. van, The Creator and the Integrity of Creation in the Fathers of the Church, Augustinian Studies 21(1990), 1-33.

Bocheński I.M., Filozofia a światopoglad, Znak 37(1985)5, 3-17.

Bronk A., Podstawy nauk o religii, Towarzystwo Naukowe KUL, Lublin 2003.

Brzegowy T., Kosmologia (kosmogonia) biblijna, w: Duch i Oblubienica mórwia: Przyjdz, red. W. Chrostowski, Vocatio, Warszawa 2001.

Brzegowy T., Pięcioksiag Mojżesza. Wprowadzenie i egzegeza Księgi Rodzaju 1-11, Biblos, Tarnów 2002.

Chlewiński Z., Fideizm wfllozofii, w: Powszechna Encyklopedia Filozofii, t. 3, red. A. Maryniarczyk, Polskie Towarzystwo Tomasza z Akwinu, Lublin 2002, 427-428.

64 Por. Jan Paweł II, Sprawa Galileusza lekcją dla współczesnych, przekł. polski, L’Osservatore Romano 1(1993), 23-26. 
Dłubacz W., Światopogląd, w: Powszechna Encyklopedia Filozofii, t. 9, red. A. Maryniarczyk, Polskie Towarzystwo Tomasza z Akwinu, Lublin 2008, 346-347. Evolution after Darwin, t. III: Issues in evolution, red. S. Tax, Ch. Calender, Chicago - Londyn 1960.

Evolution and Creation, red. E. McMullin, University of Notre Dame Press, Notre Dame 1985.

Fabbri M.V., Creazione e salvezza nel libro della Sapienza. Esegesi di Sap 1,13-15, Roma 1998.

Golbiak J., Początek Wszechświata w kosmologii kwantowej, w: Filozofia przyrody, (Seria: Dydaktyka filozofii, t. 3), red. S. Janeczek, A. Starościc, D. Dąbek, J. Herda, Wydawnictwo KUL, Lublin 2013, 255-279.

Gołębiewski M., Idea stworzenia w Biblii Hebrajskiej i teologii żydowskiej, w: Dzieci jednego Boga. Praca zbiorowa uczestników seminarium naukowego w Spertus College of Judaica w Chicago (1989), red. W. Chrostowski, Akademia Teologii Katolickiej, Warszawa 1991, 53-71.

Grzybek S., Teologia kaptańskiego opisu stworzenia świata (Rdz 1,1-2,4a), w: Początek świata - Biblia a nauka, red. M. Heller, M. Drożdż, Biblos, Tarnów 1998. Hawking S.W., Krótka historia czasu. Od wielkiego wybuchu do czarnych dziur, tłum. z ang. P. Amsterdamski, Wydawnictwo Zysk i S-ka, Poznań 2015.

Hawking S.W., Mlodinov L., Jeszcze krótsza historia czasu, tłum. z ang. J. Bieroń, Wydawnictwo Zysk i S-ka, Poznań 2007.

Heller M., Filozofia kosmologii. Wprowadzenie, Copernicus Centre Press, Kraków 2013.

Heller M., Granice kosmosu i kosmologii, Wydawnictwo Scholar, Warszawa 2005. Heller M., Pabjan T., Elementy filozofi przyrody, Copernicus Centre Press, Kraków 2014.

Heller M., Pabjan T., Stworzenie i poczatek wszechświata. Teologia - FilozofiaKosmologia, Copernicus Centre Press, Kraków 2014.

Heller M., Sens życia i sens wszechświata. Studia z teologii wspótczesnej, Copernicus Centre Press, Kraków 2015.

Heller M., Usprawiedliwienie Wszechświata, Kraków 1984.

Heller M., Życiński J., Dylematy ewolucji, Copernicus Centre Press, Kraków 2016. Interpretacja Biblii w Kościele. Przemówienie Ojca Świętego Jana Pawta II oraz Dokument Papieskiej Komisji Biblijnej, Pallottinum, Poznań 1994.

Jan Paweł II, Komentarz do Ksiag Starego Testamentu, oprac. M. Czekański, Wydawnictwo M., Kraków 2012.

Jan Paweł II, Sprawa Galileusza lekcją dla wspótczesnych, przekł. polski, L'Osservatore Romano (1993)1, 23-26. 
Kamiński S., Światopogląd-Religia - Teologia. Zagadnienia flozoficzne i metodologiczne, Towarzystwo Naukowe KUL, Lublin 1998.

Kosek J., Model budowy świata wedtug Księgi Hioba [Hi 26,5-13], w: Z badań nad Bibliq, red. T. Jelonek, Wydawnictwo Naukowe Papieskiej Akademii Teologicznej, Kraków 2003, 189-218.

Lubański M., Światopogląd, w: Katolicyzm A-Z, red. Z. Pawlak, Poznań 1997, 362-364.

Łach S., Ksiega Rodzaju. Wstęp, przektad z oryginatu, komentarz, Pallottinum, Poznań 1962.

Maryniarczyk A., Creatio ex nibilo, w: Powszechna Encyklopedia Filozofi, t. 2, red. A. Maryniarczyk, Polskie Towarzystwo Tomasza z Akwinu, Lublin 2001, 306-318.

McGrath A., Nauka i religia, tłum. z ang. M. Chojnacki, WAM, Kraków 2009.

McMullin E., Ewolucja i stworzenie, tlum. z ang. J. Rodzeń, Copernicus Centre Press, Kraków 2014.

Pabjan T., Czy nauka dowodzi istnienia Boga? Naukowa apologetyka Piusa XII, Studia Philosophiae Christianae 45(2009)2, 277-294.

Pius XII, Dowody istnienia Boga wświetle nowoczesnej nauki, w: Dokumenty Nauki Kościota, seria III, t. 2, red. T. Dobrowolski, Londyn 1952.

Poniży B., Pojęciestworzenia w leksyce i argumentowaniu Ksiegi Mądrości, w: Stowo pojednania. Ksiega Pamiatkowa z okazji siedemdziesiatych urodzin Księdza Michata Czajkowskiego, red. J. Warzecha, Biblioteka „Więzi”, Warszawa 2004, 82-96.

Romaniuk K., Zagadnienie naturalnegopoznania Boga wedtug Rz 1,18-33, Rocznik Teologii Katolickiej 24(1977)1, 59-68.

Stępień A.B., Wstęp do filozofii, Towarzystwo Naukowe KUL, Lublin 2001.

Szulakiewicz M., Poszukiwania metafizyczne, Wydawnictwo Naukowe Uniwersytetu Mikołaja Kopernika, Toruń 2014.

Ślaga S.W., Ewolucjonizm, w: Katolicyzm A-Z, red. Z. Pawlak, Poznań 1997, $117-119$.

Świerczek E., Poznanie Boga wedtug Pisma Świętego. Czy Mdr 13,1-9 i Rz 1,18-23 oraz późna tradycja żydowska uzupetniaja ogólnq naukę biblijna na temat poznania Boga?, Przegląd Kalwaryjski 11-12(2007-2008), 25-47.

Tempczyk M., Przyrodniczy obraz świata - standardowy model ewolucji Wszechswiata, w: Filozofia przyrody, (Seria: Dydaktyka filozofii, t. 3), red. S. Janeczek, A. Starościc, D. Dąbek, J. Herda, Wydawnictwo KUL, Lublin 2013, 231-254. Tomasz z Akwinu, O wieczności świata, w: Tomasz z Akwinu, Dzieła wybrane, tłum. z łac. J. Salij, W Drodze, Poznań 1984. 
Turek J., Kosmologia, w: Powszechna Encyklopedia Filozoficzna, t. 5, red. A. Maryniarczyk, Polskie Towarzystwo Tomasza z Akwinu, Lublin 2004, 885-889. Wildiers N.M., Obraz śrwiata a teologia. Od średniowiecza do dzisiaj, tłum. z niem. J. Doktór, Instytut Wydawniczy PAX, Warszawa 1985.

Wszołek S., Racjonalność wiary, Wydawnictwo Naukowe PAT, Kraków 2003. Zon J., Ewolucja i ewolucjonizm, w: Filozofia przyrody, (Seria: Dydaktyka filozofii, t. 3), red. S. Janeczek, A. Starościc, D. Dąbek, J. Herda, Wydawnictwo KUL, Lublin 2013, 87-113.

Zon J., Ewolucja, w: Powszechna Encyklopedia Filozofii, t. 3, red. A. Maryniarczyk, Polskie Towarzystwo Tomasza z Akwinu, Lublin 2003, 331-335.

Zon J., Ewolucjonizm, w: Powszechna Encyklopedia Filozofi, t. 3, red. A. Maryniarczyk, Polskie Towarzystwo Tomasza z Akwinu, Lublin 2003, 335-351.

\title{
CREATION AND EVOLUTION - TWO "PUZZLES" IN THE CHRISTIAN OUTLOOK ON LIFE
}

\begin{abstract}
The problem of the relationship between religion and science, understood as the relation between the Christian doctrine and natural sciences, is widely known and discussed today. This article undertakes a very practical approach in an effort to represent and reconsider the Christian outlook on life within the context of the encounter of two great ideas in the man of faith: creation and evolution.

A basic sketch of the Christian outlook on life along with its essential features is drawn from a proposed definition. Within this framework, we suggest an interpretation of the encounter and interaction of creation and evolution.

Dialogue provides the means to achieve a mature attitude towards reality to both the believer and those pursuing natural sciences. At the same time, it may lead to an inner integration of man and answer some current cultural crises.
\end{abstract}

Keywords: creation, evolution, creationism, evolutionism, cosmology, Christian outlook on life, science - religion dialogue, metaphysical questions

\footnotetext{
MARCIN NAPAD $Ł O$

marcin.napadlo@usz.edu.pl

Uniwersytet Szczeciński, Wydział Teologiczny, Katedra Filozofii Chrześcijańskiej

Pawła VI 2, 71-459 Szczecin
}

DOI: 10.21697/spch.2019.55.1.05 